\title{
BUILDING URBAN LOCAL GOVERNANCE FISCAL AUTONOMY THROUGH PROPERTY TAXATION FINANCING OPTION
}

\author{
Bioye Tajudeen ALUKO \\ Department of Estate Management, Obafemi Awolowo University, Ile - Ife, Nigeria \\ E-mail: btaluko@yahoo.com
}

Received 19 April 2005; accepted 31 August 2005

\begin{abstract}
The continued productivity of urban economies depends upon the provision of urban infrastructure and social services. And, a large share of the service-provision role is conventionally assigned to local government as tastes and preferences vary among individuals and communities. This requires financing the public expenditures and, although, there are other sources of revenue, taxation is very central to effective and efficient service-delivery. The paper, therefore, examines the role of property taxation in this regard with a view to promoting and building urban local governance autonomy in cities of developing world. The paper also examines the essentials of a good property tax and problems of its administration in Africa urban local governments. Consequently, a prima facie case for property tax reforms is made in order to improve the revenue-generating potentials of the tax. More importantly, the paper concludes that the real challenge towards sustainable fiscal autonomy for urban local governance in developing countries is to rally all actors or stakeholders at the policy planning and administration of property tax stages. This will ensure effective mobilization of all for the success of such tax.
\end{abstract}

KEYWORDS: Urban Local Governance; Property Taxation; Financial Autonomy; Revenue; Social Services; Developing Countries

\section{INTRODUCTION}

Three roles are conventionally assigned to the public sector: economic stabilization, income redistribution, and allocation/public service provision. The first two roles are generally assigned to central government because it has competitive advantage in executing them since local economies are too open to permit counter cyclical measures to be implemented effectively and, local attempts to address income disparities are likely to induce inefficient migration. But, a large share of the serviceprovision role is conventionally assigned to local government as tastes and preferences vary among individuals and communities, and welfare gains can be realized if consumers are in a position to choose the level and mix of services that best suit them (Dillinger, 1992; Lav- ender, 1998; Mills, 1998; Cagdas, Gur and Kurt, 2003).

The continued productivity of urban economies depends upon the adequate provision of urban infrastructure and social services. While there are many constraints on the delivery of these services, one of the most universal is finance (Dillinger op $\underline{c i t}$; Cadgas, $\underline{e t} \underline{a l} \underline{o p} \underline{c i t}$ ). The public finance or expenditures incurred in the provision of these services or infrastructure can also be categorized as national or local, the first referring to the central government which concerns itself with the whole community and the second referring to local or municipal authorities who are concerned with the local interest within their areas of jurisdictions. The latter is the focus of this paper.

Again, there are four ways of financing local or municipal authorities public expendi- 
tures: (i) local taxes; (ii) user fees; (iii) subsidies and grants, and (iv) loans. (Olowu, 1984; 1985). Local taxes and user fees are collected from the people and enterprises living in the local government jurisdiction. They can be described as resources mobilized "domestically", as opposed to subsidies and loans, which are resources mobilized outside the jurisdiction.

Of all the above sources, taxation is very central to the provision of revenues for public expenditures; and being a complex and sensitive subject has always occupied public attention for many years (Aritho, 1980; Plimmer and McGill, 2003). The term "tax" is defined in Encyclopedia Britannica as, "compulsory levy that is the most important source of government revenue." Taxes can be classified as taxes on income, taxes on wealth and taxes on expenditure. While taxes on income and wealth are regarded as direct taxes, taxes on expenditure are indirect taxes. Property tax, which is the focus of this paper, is a kind of wealth tax (Yilmaz, 1996). Generally, property taxes are confined to those taxes on land, principally buildings. Taxes on buildings can be on rental value, sale value, realized income and realized gains (Gaffney, 1973; Tideman, 1982; Dunkerley, 1983; Oates and Schwab, 1996). Property taxes are the oldest and most prevalent form of taxation and revenue-generation to government (especially local government) and, also, as a tool for guiding land use and development (Dale and McLaughlin, 1999). Yet, in all countries, property taxes are only accepted as the best minor revenue sources. For example, in developing countries property taxes accounted for only about $0.4 \%$ of Gross National Product (GNP), and about $2 \%$ of total tax revenues in 1990 s. Although, the equivalent share for the Organisation for Economic Co-operation and Development (OECD) countries remained at more than $1.33 \%$ of GNP and about $4 \%$ of all tax revenues throughout the period. Nonetheless, property taxes are important sources of subnational revenue in many countries, and more so in developing countries than in developed or transition countries. In the 1990s, prop- erty taxes accounted for $40 \%$ of all subnational taxes in developing countries, 35\% in developing countries, although only $12 \%$ in transition countries (Bird and Slack, 2002). But, Charles (1996) and Pilmer et al op cit. remarked that property tax is one of the most lucrative, yet, least tapped source of tax revenue to support urban governance in Africa.

Local authorities, whether urban or rural, in developing countries have generally continued to rely rather too recklessly on uncertain and generally dwindling grants from the central governments (Olowu, 1985; Charles, op cit; Mills, op cit; Almy, 2001; Babawale, 2002; Pilmer, $\underline{e t} \underline{a l}$ op $\underline{c i t}$; Cagdas, $\underline{e t} \underline{a l} \underline{o p} \underline{\mathrm{cit}}$ ). The authors maintain that if local governments are to effectively perform their enormous and ever increasing constitutional responsibilities, and if they are to attain the desired autonomy and provide the much required alternative power base at the grassroot level, they require an independent, viable, stable and reliable source of revenue. And, that in virtually all countries, in order to meet the above target, the focus has been on the property tax. For instance, in Nigeria, about 29 years ago, when the nationwide reform of local government was being launched the federal government observed and directed as follows:

"It must be recognized that if meaningful local government is to be expected in Nigeria, much larger financial resources are needed. In respect of local resources the only one, which can be made to yield large sums, is Property Rating, the use of which should be extended to all Local Governments progressively, beginning with the urban areas (Federal Republic of Nigeria, 1976, p3).

The power to tax may rest with the central government, regional or local (municipal) governments, or both. Generally, a country's constitution would establish basic taxing powers. In most countries the power to tax property rests with the central government. However, all or a portion of property tax revenues are assigned to local governments. The central governments may give local governments some 
power to set tax rates, to decide which properties are to be taxed, and to grant exemptions and property tax relief beyond that called for in national legislation (Almy op $\underline{c i t}$ ). Thus, there is no clear cut demarcation on which of the property taxes belong to either central government or urban local government. The allocation of taxing powers between the levels of government vary from one country to another. For example, while tenement or property rating is administered solely by the local governments in Great Britain, it is within the control of state governments in Nigeria; although, used in financing local government expenditures. In Nigeria, also, other property taxes like Capital Gains tax, Capital transfer tax and tax on realized income from properties belonging to companies are controlled by the federal government while realized income on property belonging to individuals are vested in the State Governments. But, property tax is only seen as a local tax if it is used to fund local government's activities. Does this confer autonomy of the property tax on the urban local government? Aside, and as declared in Land Administration Guidelines prepared by the United Nation Economic Commission for Europe (UNECE, 1999), any taxation systems should; (i) serve clearly defined objectives; (ii) raise significant amount of revenue; (iii) be exclusively under the control of the government authority; (iv) be administered in a way that public understands and sees as fair; (v) be relatively simple and cheap to collect; (vi) be designed to make it difficult to avoid making payments; (vii) distribute the tax burden equitably across the community; and, (viii) encourage the good use of resources (Cagdas, $\underline{e t}$ al op cit.).

Against the foregoing thicket of issues and ideas on property taxation certain questions become evident: What are the different property taxes under the control of urban local governments? What are the essentials (tax liability, tax rate, tax base and legal authority) of a property tax? What is urban local governance autonomy? How are property taxes able to sus- tain the autonomy of this urban local governance? Are there other objectives of property taxation? What is the sequence of property tax administration? What procedural reforms are required to further generate funds for local governance in developing countries? The paper attempts below, in turn, to answer some of the questions raised above with a view to demonstrating the contribution of property taxation in building urban local governments' autonomy.

\section{TYPES OF PROPERTY TAXATION}

There are variations in property taxation classification all over the world. For instance, as indicated by Munro (2000), property taxes may be classified broadly into "annual" and "incidental" taxes. Taxes levied annually on property are seen as wealth tax in every country. The annual levy, for example, tenement or property rate, may be based on the estimated market value for which the property would sell under normal circumstances, or the assessed rental value of land or property or in some countries, area of property (Dale and McLaughlin, op cit). Incidental taxes arise because of specific event (inheritance, transfer inter vivos, sale, rental) triggers the tax (inheritance tax or estate duty, capital transfer tax, Capital Gains tax, income tax), such as the sale of the property, or its change to more valuable use (Munro, $\underline{o p} \underline{c i t}$ ).

Another way by which property taxes are classified is usually in relation to their tax base which is basically the value of property, either land or building and, or both land and the improvements on it. Thus, we can have four types of taxes on land: taxes on the rental value of land, taxes on the sale value of land, taxes on realized income from land, and taxes on realized gains from the sale of land. All four taxes can be used to raise revenue and reduce incentives for speculation in land, which are generally beneficial. The third and fourth produce distortions with respect to incentives to develop land, of mitigating imperfections in capital market. All permit reduction or elimination of 
taxes with significant dead-weight losses, such as those on improvements (Tideman, op $\underline{\text { cit; }}$; Cagdas, $\underline{\text { et }} \underline{a l} \underline{o p} \underline{\mathrm{cit}}$ ).

The classifications above are not water-tight and rigid, they vary from one country to another. Besides, the power to tax may rest with the central government, regional or local (municipal) governments, or both. And, taxes are not usually seen as significant tools to influence land use because revenue is the objective (Dunkerley, op $\underline{c i t}$; Almy, $\underline{o p} \underline{c i t}$ ). But, for any of the tax to confer autonomy on the urban local government it must be a local tax, used solely to fund urban local governance activities. The notion of local tax, in particular, is very elusive. What is a local tax? There is no generally agreed definition of the concept. But, from relevant authorities (Bentick, 1979; Shoup, 1983; Olowu, 1985; Bird and Slack, $\underline{o p}$ cit; Cagdas, et al op cit) four criteria can be utilized to call a tax a local tax: (i) Its base is defined by local governments, (ii) its rate is determined by local governments, (iii) its collection is undertaken by local governments, and (v) its proceeds accrue to local governments. Is one of these criteria enough? Are the four criteria necessary? The collection criteria are not without importance, but are probably not essential. The last criteria, namely that the tax income be given to the local government, is necessary to build and sustain its financial autonomy and at the same time, reduce or eliminate reliance on grants and subventions from either the state government or the federal government. But, it is, probably, not sufficient. More importantly, none of the property taxes assigned to local governments in developing countries fulfill or meet all the four criteria above. (Dillinger, op $\underline{\text { cit }}$ ). For example, in Nigeria, there is no clear-cut division of tax responsibility amongst all the three-tier level of government in the country.

\section{ESSENTIALS OF PROPERTY TAX}

Apart from the cannons of taxation already identified early in this paper, tax base, tax rate, legal authority to impose or levy tax and the burden of liability with respect to property taxation must be clearly specified in the authorizing statutes or the constitution of the respective country or state or local government.

While tax liability indicates who bears the burden of the tax, which may or may not be shifted depending on the type of tax, the legal authority establishes the jurisdiction of the taxing authority in levying the property tax. Tax rate is the actual tax liability. In principle, there is no right level of tax rate. Nevertheless, if property tax is functioning as a price for municipal or local services, the right level is that which reflects local preferences. Local property taxes, thus, appeal more directly to the quid pro quo principle as offering to the taxpayer a more visible equivalent in services for the sacrifice involved. As, for many years, tax theorists emphasized that "taxes were the equivalent given by citizens for the benefits they derived from the state (Armitage, 1935). This is the doctrine of "Social Dividend" or the "Quid pro quo". On a national scale, services of the state or central government to the individual are difficult to measure and apportion. Therefore, central or state government restrictions on tax rates can introduce a bias against higher rates. Hence, as central or state government derives no revenue from the local property tax, it has no direct financial interest in higher yields. This calculation is reflected in the extremely low effective rates mandated by central governments in, for example, Indonesia (where the combination of a tax rate of 0.5 percent of capital value and an assessment ratio of 20 percent yields an effective tax rate of 0.1 percent) and the Philippines (where central government legislation fixes a maximum tax rate of 1 percent to 1.5 percent of capital value but mandates assessment ratios that can reduce the net tax rate to as low as 0.1 percent). Besides, progressive local property tax rates reflecting higher rates for higher-value property, exemptions or reliefs for low value property and sectoral differentiation (e.g., low or high income neighbourhood) are common in 
developing countries (Olowu, 1985; Dillinger, $\underline{o p} \underline{c i t}$ ). Tax rate structures in developing countries frequently differentiate among different land uses. Residential property is taxed at a lower rate than industrial and commercial property, and owner-occupied residential property is taxed at a lower rate than renter-occupied. Vacant land is either exempted or surcharged.

In property taxation, the tax base on which the tax rate is applied usually varies from country to country. There are usually alternatives for consideration namely the land, the building, or both the land and building collectively called the property. Dunkerley (1983) notes, further, that the main contenders of the tax base are the total property value, site value and betterment. Nonetheless, there are two most common tax bases. These are 'value' and 'area' bases. The value may be on either land or buildings/improvements or both. Where the building space will not be subject to tax, according to Bahl and Zhang (1989), this is good policy if the goal is to generate a more intensive use of land in prime urban areas. Thus, those who hold excessive vacant land for storage or make poor use of their space will pay the same tax rate per unit of land as those who build multistory buildings, move their space-intensive activities to the suburbs or lease their excess land. The taxation of land and not building space, however, does raise a special set of implementation considerations. For example, if a parcel of land is occupied by more than one user, as in multistory building, then the total taxable land area will have to be prorated amongst the occupants. This may raise difficult administrative problems and, at a minimum, will require detailed record keeping. Another problem is how to treat land in "nonproductive" uses, e.g., enterprise land used for a nursery school, a clinic, or simply open space.

In addition, the value of tax base can be the rental value, sale value, realized income and realized gains from land or building or both (property). In value based systems, usu- ally market value of the property is considered. The open market value is defined by RICS (2000) as:

"An opinion of the best price at which the sale of interest in property would have been completed unconditionally for cash consideration on the date of valuation, assuming:

(a) a willing seller;

(b) that, prior to the date of valuation, there had been a reasonable period (having regard to the nature of the property and the state of the market) for the proper marketing of the interest, for the agreement of the price and terms and for the completion of the sale;

(c) that the state of the market, level of values and other circumstances were, on any earlier assumed date of exchange contracts, the same as on the date of valuation;

(d) that no account is taken of any additional bid by a prospective purchaser with a special interest; and

(e) that both parties to the transaction had acted knowledgeably, prudently and without compulsion."

The annual rental value (ARV) and expected sales price (termed capital or market value) of taxable property are widely used. For example, the UK and France have traditionally valued property on the basis of rental value; in general, their one-time colonies in Africa and Asia do so. Also countries influenced by the United States - the Philippines, Liberia, and most of Latin America - follow the U.S. practice and define value on the basis of capital value. And, in ARV systems, classes of property for which no rental market exists are valued on a capital basis and then converted to rental value using a capitalization factor. On the other hand, in capital value systems, similarly, rental income is capitalized to yield a capital value for classes of property for which other methods of determining capital value cannot be used (Dillinger, $\underline{o p} \underline{c i t}$ ). This suggests that political credibility and administrative feasibility - 
rather than the more abstract economic arguments - should be the overriding consideration in choosing a definition of value.

In estimating market value of property, three most common valuation approaches are practiced (Friedman, 1963; RICS, op cit; Almy, $\underline{o p} \underline{c i t}$; Cagdas, $\underline{e t} \underline{a l} \underline{o p} \underline{c i t}$ ). These are comparison approach, income approach and cost approach. The comparison approach is the simplest way to estimate the market value of property by identifying another property, within the same neighbourhood, that has recently sold or let and which has identical characteristics. Cost approach is adopted where the property concerned has no identical property and seldom change hands in the market. In the commercial or industrial property valuations, income approach is applied. Whichever method is applied, what is essential in a tax valuation system is objectivity - so as to reduce opportunities for dispute or collusion - and a methodology appropriate to local skills and the market information available in the local jurisdiction. Perhaps, also, for common properties like tenements, apart from market comparison approach, a valuer could adopt mass appraisal, which depends on extrapolation, by formula, from a sample of properties. Mass appraisal is used in both capital value countries - Brazil, Mexico, and the Philippines, among others and to value owner-occupied properties in ARV countries. Some ARV jurisdictions - Anambra and Oyo States in Nigeria, for example - use mass appraisal systems to value both renterand owner-occupied property (Dillinger, $\underline{o p} \underline{\mathrm{cit}}$ ).

The other tax base is area of property. If using of market value in tax assessment is not possible, usually area based valuation system is preferred. Under this system, taxes are determined simply by multiplying a measurement of area by a rate. As pointed out by Almy op cit, area based property tax valuation systems have the advantage of being simpler to administer. In this system, only area measurements are needed. They are easier to implement because market data do not have to be collected and analysed. They are also more objective than value-based systems, in that area measurements are less contestable than value estimates. On the other hand, area-based property tax systems are less fair. For example, highly desirable properties pay the same taxes as undesirable properties (Cagdas, $\underline{\underline{e t}} \underline{\underline{a l}} \underline{\underline{o p}} \underline{\mathrm{cit}}$ ).

However, it is significant to note that central to the effective administration of a property tax is land registration and the availability of a fiscal and legal cadastre denoting the land and property holding situation in the city. This implies that in order to ensure that there is a constant source of revenue from property tax to either the central or local government, it is necessary to ensure that the tax base, which is the source of revenue, is secured and capable of serving as a revenue base in perpetuity (Mabogunje, 1992; Futa, 2004)

\section{PROPERTY TAX AND URBAN LOCAL GOVERNANCE AUTONOMY}

The word "autonomy" has been given several meanings. It means, on the one hand, the first or self government, and on the other hand, freedom from all kinds like (a) freedom to do what one thinks best; (b) freedom to act without restraint; (c) freedom without fearing anything; and, (d) freedom to receive full rights of self government (Oyewo, 2003). The issue of local government autonomy has generated a lot of debate in the developing world political discourses. These recurring debates evolved out of the increased awareness both on the part of policy makers and the people about the effectiveness of local government as harbinger of national socio-political and economic development, and the hallmark of participatory urban governance or democracy in most nations of the developing world (Adeyeye, 2003).

For instance, the 1988 World Development Report devotes an entire chapter to the importance of local government reform in developing countries, and a widely cited World Bank report states that an effective public sector in a modern developing country, depends on the ability of the central government to harness 
the resources of lower levels of government (Cochrane, 1983). Olowu and Smoke (1992) identified four factors why the reform of local governments (and building up their autonomy) in Africa have been particularly significant in this respect. First, effective local governments are perceived as providing opportunities to involve long-neglected citizens in the decisionmaking process; being the closest to the grassroots populace. And, the strengthening of African local governments is essential for the rehabilitation of national public finances and hence a means to sustainable growth. Third, local governments are perceived as having the potential - especially given Africa's rich local institutional heritage - for helping to mitigate the negative effects of structural adjustment programmes on the poor. Finally, some analysts believe that local government initiative will be required to tackle the challenges of Africa's town pressures, rapid population increase and urban growth, during a period when the severity of these problems is declining in many other parts of the world. Thus, the clamour for local government autonomy in developing countries.

In most cases, autonomy is viewed as a sort of preservation of group or private interest. It is sometimes perceived by local government functionaries as a quest for a separate government such as exist, for example, between two states or central governments; this should not be the case. Likewise, the supervisory role that the states or central governments are supposed to play should not be perceived from the perspective of the superior-subordinate relationship in which the states or central or regional governments would unilaterally dictate how the local governments should be run; and, thereby, leaving little or no room for the local governments to exercise some discretion in deciding on some critical issues that affect the lives of the people (Ake, 1992; Gboyega, 1992). In this paper, we are not concerned with autonomy based on legal authority and operational functions but rather financial autonomy, with less or non-dependence on the central or state or regional government by the urban local government for financial assistance. The challenge of urban governance here relates to how all the stakeholders - taxing authorities, taxpayers, neighbourhood organizations (NGOs), community-based organizations (CBOs), and civil society are mobilized at the planning and administration stages of property tax to boost urban local governance finances. There is therefore, some level of wisdom in public-private partnership in urban property tax administration for good governance in cities of the developing world.

Arising from the following, property taxes are reliable media for promoting urban local governance financial autonomy for several reasons (Thorncroft, 1965; Orewa, 1982; Gboyega, $\underline{o p} \underline{\text { cit; }}$; Sovetdal, 2002; Cagdas, $\underline{\underline{e t}} \underline{a l}$ ). The early importance of land as the main repository of wealth ensure for a long time that it was the chief and, often, the only source of revenue for public purposes. In Early English society, the economic reality as distinct from the mystical conception of kingship was that the sovereign was a vast landowner, supporting his armed forces and other services almost entirely on the income from the estates. The taxation of private estates arose in the main by way of reservations and services demanded by the king, in respect of his land grants (Stubbs, 1906). The position is summed up: "All the imposts of the Anglo-Saxon and Norman reigns were, so far as we know, raised on the land" (Stubbs, op cit). Besides, land is both fragile and scarce resource and also a production factor. In addition to this, land is accepted as an investment tool that provides easily gain profits without labour, especially in developing countries (Arslan, 1997).

The suitability of land or property as a source of autonomous revenue for urban local governance can further be explained as follows: Firstly, the income from land is relatively easy to collect. Land itself is immovable and if the owner is unwilling to meet this liability, it is possible for the taxing authority to track down the taxpayers or obtain the property by dis- 
tress. Secondly, the income from property is generally stable and does not fluctuate wildly from year to year; because of this, the amount that might be levied in taxation can easily be determined accurately in advance. Thirdly, landed property as an income-producing unit is indestructible. Fourthly, ownership of landed property on which the tax is based is synonymous with wealth. Therefore, ability of the taxpayer to pay is guaranteed. Lastly, property has a tendency to appreciate in value, pari passu, with the population and economic activity. It, therefore, provides a build-in mechanism against inflation, except the difficulty of arranging revaluations.

Furthermore, the IAAO (1997) and the OECD (1987) reports specify other benefits of the property tax to include the following: First, it is noted that since the property tax is independent of income taxes, it enables those with low income yet with substantial property holdings to make an appreciable contribution to the provision of local government services. Additionally, it enables municipalities to derive revenue from its residents who do not reside in the localities yet maintain properties there. Second, the property tax system is transparent as compared to other forms of taxes. Property owners can always compare what they pay with what others pay for their properties and have a fair idea of whether they are paying too much or too little taxes. Nevertheless, provisions are always made for appeals in tax laws and, as such, dissatisfied taxpayers can always appeal against any perceived unfair tax levied on them. And, finally, it should be possible for the tax authorities to vary the rates of the property tax without any threat to the tax base or migration of the property owners. With reference to the sales tax, an increase in prices of commodities from a rise in the sales tax within the locality would result in residents moving elsewhere to purchase those commodities. Thus, in the case of property, the tax increase must be very substantial to result in the sale of property and relocation of the owner.

Property tax also promotes sustainable tax base for urban local governance. This transformation would mean increasing taxation on activities which essentially subtract value from the economy, such as the use of land and other resources, while reducing taxation on activities which essentially add value to the economy, such as people's earnings, spendings and savings (Stephen, op cit). Thus, it is an important part of the case for Land Value Tax (LVT), tax on unearned increment, that this not an additional tax to burden the economy with, but an essential component in the reshaping of the taxation system to help achieve greater sustainability (Oates and Schwab, $\underline{o p}$ $\underline{\text { cit; }}$ : Stephen, op cit; Mills, op cit; Plimmer and McGill, op cit).

In spite of the foregoing, the large infusion of grant money from federal government in Nigeria, as in many other developing countries, which increased from less than 2 percent of federally collected revenues in 1976 and 15 percent in 1992 to about 30 percent in 2004 currently, has boosted the coffers of local governments in Nigeria generally. While access to such funds may help boost the provision and maintenance of local infrastructures such as local roads, markets, motor-parks, agricultural ventures, elementary schools and basic health facilities, many local governments may abandon the exploitation of local revenue sources. Experience from developing countries, in these circumstances, shows that local governments have remained dangerously dependent on transfer incomes whose administration has left much to be desired, besides the uncertainty occasioned by the eccentricities of the monoeconomic nature/characteristic of these countries in the international market (Smith, 1982; Olowu, 1989; Bello-Iman, 1990; World Bank, 1990; Futa, op cit).

But, in contrast to the national trend in Nigeria, whereby local revenues have declined in absolute and relative terms since the 1976 reform (Smith, 1982; Bello-Iman, 1990; World Bank, 1990), Olowu (1992) observed that the two Lagos city council municipalities then sustained their major internally generated rev- 
enues from 1963 to 1987 . Throughout this period, both before and after the local government reform of 1976, local revenues were generally responsible for more than half of the city's needs for revenue. And, it was noted that the largest share of these internal revenue sources came from the property taxes, which was first collected in the area in 1915 . Thus, Olowu (1992, p19) points out as follows:

"One of the most important results of the global reform of local governments in Nigeria in 1976 was to initiate a progressive increase in the amount of monetary transfer to local governments (LGs) by federal and state governments (especially the former). The proportion of federally collected revenues devoted to LGs increased rapidly from less than 2 percent in 1976 to 15 percent in 1990. This enabled Nigerian LGs to play a more visible role in total public expenditures. On the other hand, huge federal transfers have led to sharp declines in absolute and relative terms in locally generated revenues. The two Lagos municipalities are able to generate up to 50 percent of their total revenues. In contrast, the average for all local governments in the country is 4-5 percent. The relative large internal revenue sources in the two Lagos municipalities results in generous surpluses, which they are able to channel into capital development or special project expenditures. The single most important internal revenue source is the property tax, which is not even collected in some other large cities, such as Kano, Ogbomosho and Sokoto"

The above has positive implication towards building or improving the financial autonomy of our local governments; although, implementing property taxation in developing countries is a difficult task in view of the legal, technical and political constraints (or administrative bottlenecks) to be tackled.

\section{PROPERTY TAX ADMINISTRATION}

Tax administration is the final stage and the ultimate goal of a tax system. However sophisticated a tax system is, the time it takes to complete all its stages and the cost incurred, the system will be ineffective if the amount of revenue it generates is too low relative to the estimated amount (Omopariola and Nassar, 1985-86). An adverse variance fiscal revenue can be brought about by several factors, including tax evasion, avoidance, concession and other tax delinquencies reflecting the problems associated with tax administration including collection capacity of a particular Tax Authority (Kelly, 1992; 1993).

Usually, a distinction is made between tax evasion and tax avoidance (Omopariola and Nassar, $\underline{o p} \underline{\text { cit }}$ ). The first act refers to an illegal act which implies paying less than established by law or not paying them at all. In the case of tax avoidance the procedure used to diminish the tax burden is in accordance with the law using existing tax loopholes. Also, in tax concession, certain behaviour of the taxpayer is actually sought. Thus, any type of investment incentives (accelerated depreciation, initial allowances or reliefs or exemptions, etc.) are typical examples of concessions while payment of less tax by considering income as capital gain would be an example of tax avoidance (Kelly, 1992).

On the strength of the above, Dillinger op cit opined that in most developing countries, property tax reforms must not be limited to policy because the quality of tax administration is poor, the burden of the tax falls haphazardly on those unable to exploit its weaknesses. Raising rates alone would exaggerate these inequalities. The author maintained that reform efforts must, therefore, address problems in administration, and further identified five stages of property taxation administration to include: Discovery, Valuation, Assessment, Billing and Collection. And, the performance of revenue raised depends upon the cumulative performance of all the five steps. It is also important to note that the sequence is an ongoing, not a one-time event.

The objective of discovery and identification is to find all the properties subject to taxation 
and obtain the information needed to impose the tax either by self-declaration or government inventory. It is submitted that voluntary subscription to public services, apart from being a Utopian idea, would also be unreliable and, as such, difficult to budget for. Consequently, contributions to public services are therefore made compulsory demands, through government inventory, from citizens. Valuation is usually undertaken either by the professional valuers or through updating and interpolation of property information by the taxing authority. Success at collection is essentially a matter of information management and leverage: knowing who owes what, and having the means and incentive to induce them to pay. Also, an appropriate legal definition of liability and notification can simplify the billing function and increase the taxing authority's leverage over delinquents.

But, the environment of property taxation is more difficult in developing countries than in industrial nations (Dillinger, $\underline{o p} \underline{\mathrm{cit}}$; Kelly $\underline{o p} \underline{\text { cit; }}$ Cagdas $\underline{\underline{e t}} \underline{a l}$ ). Dillinger op cit asserts:

"The basic data on which the property tax is based is inaccessible or unreliable. Base maps on which property discovery and identification would be based are non-existent. The market data on which valuations are based is unreliable, as property markets are driven underground by high transaction taxes and rent controls. Data on property ownership is inaccessible, either because ownership is disputed, or because deeds registries are unwilling or unable to cooperate with taxing authorities. The rapid growth of cities in developing countries exacerbates the difficulty in administering the property tax, as subdivisions and new construction must be constantly discovered and incorporated if the tax base is to reflect the physical growth of the city."

In the literature some of the problems were identified as relating to either policy matters or administration of property taxation in developing nations. Some of these problems are

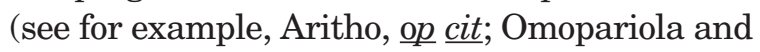
Nassar, op cit; Olowu, op cit; Kelly, op cit;
Gboyega, $\underline{o p} \underline{c i t}$; Dillinger, $\underline{o p} \underline{c i t}$; Rabiu, 1998; Cagdas, $\underline{\text { t }} \underline{a l} \underline{\underline{o p}} \underline{\mathrm{cit}}$ ) as follows:

- Lack of political will to introduce the property taxation system in a country. Hicks (1961) noted in her book, that in the former Western Region in Nigeria, "there is much resistance to the introduction of property rating, said to be due to the fact that councilors are large owners of urban real estates." Furthermore, she showed that, "in Ibadan in 1958, the caretaker government passed a resolution introducing property rating but this decision was reversed when the elected council was restored".

- Inadequate or obsolete laws on property taxation inherited from colonial masters by their colonies in Africa and, developing world in general. It also includes nonconsolidation of tax laws.

- Absence of trained personnel, particularly professional valuers. The archiles' heel of property taxation is that of assessment, valuation and revaluation of property.

- Lack of awareness of revenue raising opportunities of property taxation by most urban local governments in developing nations. Not only is this true, but, also there has been deliberate ignorance on the part of some officials who can influence policy or the execution.

- Total absence of suitable and enforcement machinery. This is essential not only as a matter of principle but also to induce public confidence.

- Environmental problems, which differ from one country to another, such as: inadequate physical and infrastructural facilities; postal and telecommunication delays; administrative inefficiencies and bottlenecks, bribery and corruption, etc., and organizational problems including bureaucracy arising from the structure of taxing authorities.

- Lack of housing census and land tenure security including multiplicity of property taxes as well as corruption in the taxing 
system affects successful implementation of property tax system in most developing countries.

\section{CONCLUSION}

The paper, so far, has demonstrated that property taxation, in developing nations, can be used to promote fiscal measure, particularly, to the financial autonomy of urban local governance. It has also tried to show that property taxation is bedeviled with policy and administration problems. And, in addressing these problems, reform strategies according to Babawale, op cit, must be based on the following principles:

(i) The need to relate the reforms to the existing property tax structure.

(ii) The reforms must take cognizance of the peculiar social and economic environment of the country.

(iii) The property tax must be treated as a "system approach".

(iv) The proposed reforms must be in harmony with the broader government fiscal policy.

(v) The reforms must satisfy the usual cannons of taxation; although no tax can conform absolutely.

(vi) Reform is a continuous process.

In view of the foregoing background, the following proposals, in addition to those earlier pointed out in the paper, are put forth in order to develop a viable financial autonomy of urban local governance in the cities of developing nations:

(a) The adoption of cadastre through the use of Geographic Positioning Information (GPI) will assist in identification and discovery of properties for taxation purpose. Cadastre has become an important activity field due to its functions in economic development and environmental management in a global world. When the data access has been getting easy, users need more information about ownership, plan, valuation and their interaction to each other and this cause increasing direct or indirect demands for cadastre in property tax administration.

(b) Codification and revision of obsolete property taxation laws to be in line with the economic and social development of a country. A code of property tax law, like any other area of tax law, is a complete statement of the entire law on the subject with which it deals.

(c) Training of existing and, recruitment of new technical staff for property tax administration. Besides, property valuation system must guide against inappropriate valuation basis, inappropriate method, poor valuation skill, lack of relevant data and wide revaluation intervals. For instance, property valuation needs to be updated frequently to achieve increased revenue in proportion to the appreciation in real property value over time. Nevertheless, revaluation exercise is usually costly and would further affect the lean financial resources of most urban local governments. Perhaps, in between the revaluations, which is usually 5 years interval, the system should be able to take advantage of increases in value and maintain level of property tax by means of indexation carried out annually by staff of taxing authorities. This must be linked to such inflation indicators as national consumer price index, indices on the rate of increase in property value, construction cost, etc.

(d) Putting in place administrative and policy measures to improve or influence, positively, the behaviour of the taxpayers, vis-à-vis, the taxing authorities. Such measures may include increased publicity of tax laws, carefully designed tax returns, aid in preparing returns, etc. Other measures may also depend on the extent to which the tax 
delinquencies were induced by the high rates of taxation and the extent to which taxpayers are prepared to accept with equanimity, the unequal burden, with people in the same or in different conditions (horizontal or vertical equity).

Finally, and more importantly, the real challenge for urban local governance is to rally all actors in an inclusive city - government, civil society, professionals, NGOs, CBOs, etc., at the planning and administration stages of property taxation. This is akin to promoting public-private partnership in property tax planning and implementation stages. This is important if the voluntary co-operation of all the actors are to be induced and revenue-generating potentials of property taxation are to be realized by the urban local governments. This will, therefore, assist in developing the financial autonomy of urban local governance, especially in Africa and, other developing countries of the world.

\section{REFERENCES}

Adeyeye, M. (2003) Democracy, local government and the crisis of autonomy in Nigeria, in Yakubu, J.A. (2003) ed., Socio-Legal Essays in Local Government Administration In Nigeria, Demyaxs Law Books, Ibadan, p. 24-39.

Ake, C. (1992) The Feasibility of Democracy in Africa, Aredu, Ibadan.

Almy, R. (2001) A Survey of Property Tax Systems in Europe, Department of Taxes and Customs, The Ministry of Finance Republic of Slovenia, March.

Aritho, G.M.G. (1980) Rating: Local Property Taxation in Kenya. The Tropical Environment, University of Nigeria, Nsukka, p. 41-70.

Armitage, S.G. (1935) Principles and Methods of Taxation, John Murray, London.

Arslan, R. (1997) Arazi Kullanis Ekononusi Yildiz Teknik Universitesi Yayini, Yayin No. YTU.MF. YK-97.0315, Istanbul.

Babawale, G.K. (2002) Reform Proposals in Nigeria, Proceedings of a National Conference on Land Management and Property Tax Reform in Nigeria, University of Lagos, p. 61-71.
Bahl, R. and Zhang, J. (1989) Taxing Urban Land in China, Discussion paper, Infrastructure and Urban Development Department, The World Bank, Washington, D.C., March.

Bello-Iman, I. B. (ed) (1990) Local Government Finance in Nigeria, Nigerian Institute of Social and Economic Research, Ibadan.

Bentick, B.L. (1979) The Impact of Taxation and Valuation Practices on the Timing and Efficiency of Land Use. Journal of Political Economy, 87, p. 859-868.

Bird, M.R. and Slack, E. (2002) Land and Property Taxation: A Review, World Bank, Washington, D.C., March.

Cadgas, V., Gur, M. and Kurt, V. (2003) Property Taxation and Management, Paper presented at the $2^{\text {nd }}$ FIG Regional Conference, Marrakech, Morocco, December 2-5.

Charles (1996) as quoted in Babawale, G.K. (2003), op cit supra.

Cochrane, G. (1983) Policies for Strengthening Local Government in Developing Countries, World Bank Staff Working Paper No. 582, The World bank, Washington, D. C.

Dale, P.F. and McLaughin, J.D. (1999) Land Administration, Oxford University Publications, New York.

Dillinger, D. (1992) Urban Property Tax Reform Guidelines and Recommendations, UMP paper 1, The World Bank, Washington, D.C.

Dunkerley, H.B. (1983) Urban Land Policy: Issues and Opportunities, a World Bank Publication, Oxford University Press, New York.

Federal Republic of Nigeria (FRN) (1976), Guidelines to Local Government Reform, Government Printers, Lagos.

Friedman, J. (1963) Encyclopedia of Real Estate, $5^{\text {th }}$ ed., Prenticce-Hall, Englewood-Cliffs.

Futa, A. B. (2004) Property Taxes and Revenue Generation: The Case of Sweden, and Unpublished MSc. Thesis, Department of Infrastructure, Building and Real Estate Economics, Royal Institute of Technology, Stockholm, February.

Gaffney, M.M. (1973) Tax Reform to release land, in Marion, C. (1973) ed., Modernizing Urban Land Policy, John Hopkins, Baltimore, p. 115152.

Gboyega, A. (1992) Local Government Autonomy and Intergovernmental Relations in Nigeria, in Ayoade, J.A.A. et al. (ed.) (1992), Grassroot De- 
mocracy and The New Local Government System In Nigeria, Centre for Democratic Studies, Abuja, p. 34-58.

Hicks, V.K. (1961) Development from Below: Local Government and Finance in Developing Countries of the Commonwealth, Clarendon Press, London.

IAAO (International Association of Assessing Officers) (1997) Standard on Property Tax Policy, IAAO, Chicago.

Kelly, R. (1992) Implementing Tax Reform in Developing Countries: Lessons from the Property Tax in Indonesia. Review of Urban and Development Studies, 4(2), p. 93-208.

Kelly, R. (1993) Property Tax Reform in Indonesia: Applying a Collection-Led Strategy. Bulletin of Indonesia Economic Studies, 29(1), p. 16-19.

Lavender, S. (1998) Property-Based Taxation: International Perspectives and Applications, Proceedings of International Seminar on PropertyBased Taxation, Organised by The Nigerian Institution of Estate Surveyors and Valuers, Abuja, paper 6 .

Mabogunje, A. L. (1992) Perspective on Urban Land and Urban Management Policies in Sub-Saharan Africa, World Bank Technical Paper No. 196, Africa Technical Department Series, The World Bank, Washington, D. C.

Mills, E.S. (1998) Is Land Taxation Practical? Illinois Real Estate Letter, Published by the Office of Real Estate Research, University of Illinois at Urbana - Champaign, Fall.

Munro, P.F. (2002) Best Practices for Property/Land Tax and Valuation Administration in a Decentralized System, Proceedings of the International Conference on Land Policy, Jakarta, Indonesia, July 26.

Oates, W.E. and Schwab, R.M. (1996) The Impact of Urban Land Taxation: The Pittsburgh Experience, a revised paper - unpublished, Department of Economics, University of Maryland, $50 \mathrm{p}$.

OECD (Organization for Economic Co-operation and Development) (1991) Urban Infrastructure: Finance and Management, OECD, Paris.

Olowu, D. (1984) Local Governments and Urban Development in Nigeria, in Abiodun, J. (1984) ed., Urban and Regional Planning Problems in Nigeria, University of Ife, Ile-Ife.

Olowu, D. (1985) Prospects of The Property Rates As An Additional Revenue Source for Nigerian
Local Governments. Quarterly Journal of Administration, OAU, Ile-Ife, p. 305-322.

Olowu, D. (1989) Local Institutions and Socio-economic Development. Canadian Journal of African Studies, 23, p. 201-231.

Olowu, D. (1992) Urban Local Government Finance in Nigeria: The Case of Lagos Municipal Area. Public Administration and Development, 12, p. 19-38.

Olowu, D. and Smoke, P. (1992) Determinants of Success in African Local Governments: an Overview. Public Administration and Development, 12, p. 1-17.

Omopariola, O. and Nassar, M.L. (1985-86) Improving the machinery for tax collection in Nigeria. The Quarterly Journal of Administration, $\mathrm{XX}(1 \& 2)$, p. 67-80.

Orewa, G.O. (1982) Property Rating As A Source of Revenue, Symposium organized by The Nigerian Institution of Estate Surveyors and Valuers - Bendel State Branch, Benin-City, November 27, p. 5-10.

Oyewo, A.T. (2003) Local Government Autonomy Theoretical and Conceptual Framework, in Yakubu, J.A. (2003) ed., Socio-Legal Essays in Local Government Administration in Nigeria, Demyaxs Law Books, Ibadan, p. 54-63.

Plimmer, F. and McGill, G. (2003) Land Value Taxation: Betterment Taxation in England and the Potential for Change, TS9 New Professional Tasks - Developing the Profession, U.K. 16 p.

Rabiu, S.A. (1998) The Current Property Based Taxes in Nigeria: Administrative, Logistics and Procedural Problems in Implementation, International Seminar on Property-Based Taxation, NIESV, Abuja, Paper 3.

RICS (2000) RICS Appraisal and Valuation Manual, RICS, UK.

Sevetdal, H. (2002) Land Administration and Land Management: An Institutional Approach, Proceedings of XXII International Federation Internationale des Geometres (FIG) Congress, Washington, D.C. April 19-26.

Shoup, D.C. (1983) Intervention through Property Taxation, in Dunkerley, H.B. (1983) ed., Urban Land Policy: Issues and Opportunities, A World Bank Publication, Oxford University Press, New York, p. 132-152.

Smith, B. (1982) The Revenue Position of Local Governments in Nigeria. Public Administration and Development, 2(1), p. 1-13. 
Stubbs, W. (1906) Lectures in Early English Theory, Ed. A. Hassall, Longmans Green \& Co., London, p. 301-302.

Thorncroft, M. (1965) Principles of Estate Management, Estates Gazette Limited, London.

Tideman, N. (1982) A Tax on Land Is Neutral. National Tax Journal, 35, p. 109-111.

TODAIE (2003) Yerel Yonetimler Arastamare Egitim Merkezi, http://www.britannica.com/, July 2003.
United Nations Economic Commission for Europe (UNECE) (1999), Land Administration Guidelines, UNECE, New York, U.S.A.

World Bank (1990) Nigeria: Local Government Development Sector Study, World Bank, Washington, D. C.

Yilmaz, H. (1996) as quoted in Cagdas, V., Gur, M. and Kurt, V. (2003), op cit, supra.

\section{SANTRAUKA}

\section{MIESTŲ SAVIVALDOS FISKALINĖS AUTONOMIJOS KŪRIMAS NAUDOJANT FINANSAVIMĄ IŠ NUOSAVYBĖS APMOKESTINIMO}

\section{Bioye Tajudeen ALUKO}

Ilgalaikis miesto ūkio našumas priklauso nuo miesto infrastruktūros ir socialinių paslaugų teikimo. Didelis vaidmuo paslaugų teikimo srityje paprastai priskiriamas vietos valdžiai, nes asmenų ir bendruomenių skoniai bei polinkiai skiriasi. Dèl to reikia padengti viešąsias išlaidas. Nors egzistuoja kitų pajamų šaltinių, mokesčiai yra labai svarbūs kokybiškoms paslaugoms teikti. Todèl šiame darbe tiriamas nuosavybès apmokestinimo vaidmuo, miestų savivaldos autonomiją propaguojant ir kuriant besivystančių valstybiu miestuose. Darbe nagrinėjama nuosavybès mokesčio esmè bei jo administravimo problemos Afrikos miestų savivaldos organizacijose. Akivaizdu, kad reikalinga nuosavybès mokesčių reforma, kuri leistų geriau pasinaudoti pajamų surinkimo iš mokesčių potencialu. Darbe taip pat pateikiama svarbi išvada, jog kuriant subalansuotą iždo politiką pagrindinis uždavinys, tenkantis miestų savivaldos organizacijoms besivystančiose šalyse, - pasistengti visas suinteresuotas puses įtraukti ị politikos planavimą ir nuosavybès mokesčiu administravimą. Tai garantuos efektyvų visuotinị mobilizavimą ir šio mokesčio sẻkmę. 